\title{
Effects of rumen-protected lysine and histidine on milk production and energy and nitrogen utilization in diets containing hydrolyzed feather meal fed to lactating Jersey cows
}

\author{
D. L. Morris ${ }^{1}$ (i) and P. J. Kononoff ${ }^{1 *}$ () \\ ${ }^{1}$ Department of Animal Science, University of Nebraska-Lincoln, Lincoln 68583
}

\begin{abstract}
Hydrolyzed feather meal (HFM) is high in crude protein, most of which bypasses rumen degradation when fed to lactating dairy cows, allowing direct supply of AA to the small intestine. Compared with other feeds that are high in bypass protein, such as blood meal or heat-treated soybean meal, HFM is low in His and Lys. The objectives of this study were to determine the effects of supplementing rumen-protected (RP) Lys and His individually or in combination in a diet containing $5 \%$ HFM on milk production and composition as well as energy and $\mathrm{N}$ partitioning. Twelve multiparous Jersey cows (mean \pm SD: $91 \pm 18 \mathrm{~d}$ in milk) were used in a triplicated $4 \times 4$ Latin square with 4 periods of $28 \mathrm{~d}$ (24-d adaptation and 4-d collection). Throughout the experiment, all cows were fed the same TMR, with HFM included at $5 \%$ of diet DM. Cows were grouped by dry matter intake and milk yield, and cows within a group were randomly assigned to 1 of 4 treatments: no RP Lys or RP His; RP Lys only $[70 \mathrm{~g} / \mathrm{d}$ of Ajipro-L (24 g/d of digestible Lys), Ajinomoto Co. Inc., Tokyo, Japan]; RP His only [32 g/d of experimental product (7 g/d of digestible His), Balchem Corp., New Hampton, NY]; or both RP Lys and His. Plasma Lys concentration increased when RP Lys was supplemented without RP His $(77.7$ vs. $66.0 \pm 4.69 \mu M)$ but decreased when RP Lys was supplemented with RP His (71.4 vs. 75.0 $\pm 4.69 \mu M$ ). Plasma concentration of 3-methylhistidine decreased with RP Lys (3.19 vs. $3.40 \pm 0.31 \mu M)$. With RP His, plasma concentration of His increased (21.8 vs. $18.7 \pm 2.95 \mu M)$. For milk production and milk composition, no effects of Lys were observed. Supplementing RP His increased milk yield ( 22.5 vs. $21.6 \pm 2.04 \mathrm{~kg} / \mathrm{d}$ ) and tended to increase milk protein yield (0.801 vs. $0.772 \pm 0.051 \mathrm{~kg} / \mathrm{d})$. Across treatments, dry matter intake $(18.5 \pm 0.83 \mathrm{~kg} / \mathrm{d})$ and energy supply $(32.2 \pm$ 2.24 Mcal of net energy for lactation) were not differ-
\end{abstract}

Received February 14, 2020.

Accepted April 2, 2020.

*Corresponding author: pkononoff2@unl.edu ent. Supplementing RP His did not affect N utilization; however, supplementing RP Lys increased N balance ( 25 vs. $16 \pm 9 \mathrm{~g} / \mathrm{d}$ ). The lack of production responses to RP Lys suggests that Lys was not limiting or that the increase in Lys supply was not large enough to cause an increase in milk protein yield. However, increased N balance and decreased 3-methylhistidine with RP Lys suggest that increased Lys supply increased protein accretion and decreased protein mobilization. Furthermore, His may be a limiting AA in diets containing HFM.

Key words: rumen-protected lysine, rumen-protected histidine, hydrolyzed feather meal

\section{INTRODUCTION}

Hydrolyzed feather meal (HFM) is a widely available high-CP (92\%) feedstuff that may be used as a source of protein in lactating dairy cow rations. Although HFM is high in CP, of which approximately $65 \%$ is RUP, Lys (2.6\% of CP) and His ( $1.2 \%$ of CP) content are low compared with other commonly used feeds such as blood meal (6.0 and 6.4\% of CP for Lys and His, respectively; NRC, 2001). Because the Lys and His content of HFM is low, feeding HFM may result in deficiencies in AA (Stahel et al., 2014). We recently fed HFM at $0,3.3,6.7$, and $10 \%$ of diet DM as a replacement for blood meal and nonenzymatically-browned soybean meal (Morris et al., 2020). In this study, DMI was maintained when HFM was fed up to $6.7 \%$ of diet DM and ECM was similar across treatments, but milk protein linearly decreased with increasing HFM inclusion. Given the low Lys and His content of HFM compared with blood meal, these AA may have limited milk protein synthesis. Therefore, research is needed to understand how Lys and His supply may influence performance of lactating cows fed high-HFM diets.

Feeding diets with HFM as the primary protein source, compared with blood meal or soybean meal, is an excellent scenario from which to evaluate potentially limiting AA. Along with Met, Lys (NRC, 2001; Giallongo et al., 2016) and His (Lee et al., 2012; Giallongo 
et al., 2015, 2016) are commonly studied as potentially limiting AA in lactating dairy cows. The NRC (2001) suggests that maximal milk protein concentration and yield are achieved when Lys is 7.1 and $7.2 \%$ of MP, respectively. In corn-based diets, these concentrations of Lys may be difficult to reach, leading to a more practical targets of 6.6 for Lys as a percent of MP (Schwab et al., 2005). In several recent studies, increasing Lys supply via rumen-protected (RP) Lys increased milk protein concentration in some (Paz and Kononoff, 2014; Giallongo et al., 2016; Fleming et al., 2019a) but not in others (Paz et al., 2013; Arriola Apelo et al., 2014), and generally did not affect milk protein yield. Therefore, the effects of increasing Lys supply on milk protein production remain unclear. In diets low in MP and His, increased milk protein yield has been observed with abomasal infusion of His (Vanhatalo et al., 1999; Huhtanen et al., 2002) or by feeding RP His (Giallongo et al., 2015; Zang et al., 2019). The effects of RP Lys and His on milk protein appear to be influenced, at least in part, by another co-limiting AA. For example, Giallongo et al. (2016) reported that when individually supplementing Met, Lys, and His to an MP-deficient diet, milk protein yield was not affected; however, when all 3 AA were supplemented simultaneously, milk protein yield increased by $0.10 \mathrm{~kg} / \mathrm{d}$. The results of the study by Giallongo et al. (2016) would suggest that response to increased Lys supply may, at least in part, be influenced by the supply of His; however, the interactive nature between supply of Lys and His has not been studied. Therefore, the objectives of the current study were to determine the effects of supplementing RP Lys and His individually or in combination, in a diet containing HFM, on milk production and energy and $\mathrm{N}$ partitioning in lactating dairy cows. We hypothesized that the addition of Lys and His would individually and additively increase milk protein production and thus increase partitioning of energy and $\mathrm{N}$ toward milk.

\section{MATERIALS AND METHODS}

\section{Animals and Treatments}

The University of Nebraska-Lincoln Animal Care and Use Committee approved animal care and experimental procedures. Twelve multiparous Jersey cows [(average \pm SD) $91 \pm 18$ DIM at the beginning of the experiment) sourced from a commercial dairy were used. Sample size was based on previous work at the University of Nebraska-Lincoln (Reynolds et al., 2019). Cows were housed in individual tiestalls equipped with rubber mats, in a temperature-controlled $\left(20^{\circ} \mathrm{C}\right)$ barn at the Dairy Metabolism Facility in the Animal Science Complex at the University of Nebraska-Lincoln, and milked at 0700 and $1800 \mathrm{~h}$. All cows were less than 40 d pregnant at the end of the last experimental period; thus, fetal energy was assumed to be zero (NRC, 2001).

The experimental design was a triplicated $4 \times 4$ Latin square balanced for carryover effects, with 4 periods of $28 \mathrm{~d}$. Cows were fed the same TMR, with HFM included at $5 \%$ of diet DM, throughout the experiment. Cows were grouped by DMI and milk yield, and cows within a group were randomly assigned to treatment sequence (randomization and enrolment was completed by D. L. Morris). Treatment sequence was based on Kononoff and Hanford (2006). Treatments were as follows: (1) no supplemental Lys and no supplemental His (LYSOHIS0); (2) supplemental RP Lys only (LYS+HIS0; $70 \mathrm{~g} / \mathrm{d}$ of Ajipro, Ajinomoto Co. Inc., Tokyo, Japan); (3) supplemental RP His only (LYSOHIS+; $32 \mathrm{~g} / \mathrm{d}$ of experimental product, Balchem Corp., New Hampton, NY); or (4) both supplemental RP Lys and His (LYS+HIS+; $70 \mathrm{~g} / \mathrm{d}$ of Ajipro and $32 \mathrm{~g} / \mathrm{d}$ of experimental product). Treatments were applied at time of feeding by top dressing evenly over the TMR. In general, treatments were known by personnel; however, because most measurements were objective, outcomes likely were not biased. Three sources of HFM were used (American Proteins Inc., Cumming, GA; Pilgrim's, Greeley, CO; Simmons Foods, Siloam Springs, AR), to minimize effects of individual source and to represent commercially available HFM. To accommodate the amount of HFM received from each source, these sources of HFM were blended in the following proportions: $33.3,18.6$, and $48.1 \%$ of DM for American Protein Inc., Pilgrim's, and Simmons Foods, respectively. Concentrate mixes for each treatment that included all dietary ingredients except for forages and cottonseed hulls (Table 1) were mixed at the University of Nebraska-Lincoln feed mill. Dietary ingredients for the base diet (corn silage, alfalfa hay, and concentrate) were placed in a Calan Data Ranger (American Calan Inc., Northwood, NH), mixed, and fed as a TMR once daily at $0930 \mathrm{~h}$, with a target refusal rate of $5 \%$. Each period included $24 \mathrm{~d}$ of ab libitum diet adaptation, followed by $4 \mathrm{~d}$ of collection. To limit refusal during collection, cows were fed at $100 \%$ of the prior week's intake.

The ruminal and intestinal digestibility of HFM and RP AA used in the current study were estimated using the mobile bag technique (Paz et al., 2014). Briefly, each product was placed in the rumen $(16 \mathrm{~h})$, followed by a pepsin- $\mathrm{HCl}$ bath $(3 \mathrm{~h})$, and, finally, inserted into the duodenum and allowed to pass with digesta. The entire procedure was replicated in 2 lactating dairy cows. Samples incubated in the rumen and passed through the duodenum were analyzed for N (Leco FP-528 N Combustion Analyzer, Leco Corp., St. Joseph, MI). 
Table 1. Ingredient, chemical composition, and particle size distribution of the basal TMR fed to all experimental cows (\% of DM)

\begin{tabular}{lc}
\hline Item & Basal TMR \\
\hline Ingredient & \\
Corn silage & 39.0 \\
Alfalfa hay & 16.0 \\
Hydrolyzed feather meal & 5.0 \\
Corn grain, ground & 17.5 \\
Soyhulls & 9.3 \\
Soybean meal & 1.7 \\
Molasses & 3.0 \\
Whey & 2.5 \\
Fat ${ }^{1}$ & 2.5 \\
Urea & 0.55 \\
Rumen-protected Met ${ }^{2}$ & 0.09 \\
Mineral-vitamin mix & 2.86 \\
Chemical composition & \\
DM & $57.6(2.47)$ \\
CP & $17.1(0.42)$ \\
ADF & $22.2(1.34)$ \\
NDF & $32.4(0.72)$ \\
NDF ${ }^{4}$ & $31.7(0.82)$ \\
Starch & $26.3(1.20)$ \\
Crude fat & $5.3(0.63)$ \\
Ash & $7.9(0.28)$ \\
Particle size & \\
>19.0 mm, \% as is & $6.0(2.27)$ \\
8.0-19.0 mm, \% as is & $34.9(4.74)$ \\
$1.18-8.0$ mm, \% as is & $37.1(4.99)$ \\
$<1.18$ mm, \% as is & $22.0(0.72)$ \\
819.0 mm, \% of DM & $5.3(1.84)$ \\
1.18-8.0 mm, \% of DM & $29.4(3.27)$ \\
$<1.18$ mm, \% of DM & $40.7(3.01)$ \\
\hline
\end{tabular}

${ }^{1}$ Energy Booster 100 (Milk Specialties, Eden Prairie, MN).

${ }^{2}$ Smartamine M (Adisseo, Alpharetta, GA).

${ }^{3}$ Contained per kilogram of premix: $319 \mathrm{~g}$ of $\mathrm{CaCO}_{3}, 269 \mathrm{~g}$ of $\mathrm{NaHCO}_{3}$, $175 \mathrm{~g}$ of $\mathrm{Ca}_{2} \mathrm{PO}_{4}, 112 \mathrm{~g}$ of $\mathrm{MgO}, 94 \mathrm{~g}$ of salt, $17 \mathrm{~g}$ of vitamin premix $(14,850 \mathrm{IU} / \mathrm{g}$ of vitamin $\mathrm{A}, 3,850 \mathrm{IU} / \mathrm{g}$ of vitamin $\mathrm{D}$, and $90 \mathrm{IU} / \mathrm{g}$ of vitamin $\mathrm{E})$, and $14 \mathrm{~g}$ of trace mineral premix $(180,000 \mathrm{mg} / \mathrm{kg}$ of $\mathrm{Zn}$, $150,000 \mathrm{mg} / \mathrm{kg}$ of $\mathrm{Mn}, 25,000 \mathrm{mg} / \mathrm{kg}$ of $\mathrm{Cu}, 2,600 \mathrm{mg} / \mathrm{kg}$ of I, 2,300 $\mathrm{mg} / \mathrm{kg}$ of $\mathrm{Co}, 1,000 \mathrm{mg} / \mathrm{kg}$ of $\mathrm{Fe}$, and $820 \mathrm{mg} / \mathrm{kg}$ of Se).

${ }^{4} \mathrm{NDF}_{\mathrm{OM}}=\mathrm{NDF}$ corrected for ash.

Residue from bags that were incubated in the rumen was assumed to bypass rumen degradation, and the disappearance in sample from the duodenally incubated bags was assumed to represent intestinal digestibility of the bypass fraction. The AA content of RP Lys and RP His was determined as the $\mathrm{N}$ content of the product divided by the $\mathrm{N}$ content of the corresponding AA $(19.2 \%$ for Lys and $27.1 \%$ for His).

\section{Sample Collection and Analysis}

Individual feed ingredients were sampled daily during collection periods and frozen at $-20^{\circ} \mathrm{C}$. Corn silage was dried at $60^{\circ} \mathrm{C}$ for $48 \mathrm{~h}$, and then all feeds were ground to pass a 1-mm screen (Wiley Mill, Arthur A. Thomas Co., Philadelphia, PA). A subsample of ground feed was sent to Cumberland Valley Analytical Services Inc. (Waynesboro, PA) for analysis of N (Leco FP-528 N
Combustion Analyzer, Leco Corp.), NDF with sodium sulfite (Van Soest et al., 1991) and $\alpha$-amylase and corrected for ash contamination, ADF (method 973.18; AOAC International, 2000), ADL (Goering and Van Soest, 1970), sugar (DuBois et al., 1956), starch (Hall, 2009), crude fat (2003.05; AOAC International, 2000), ash (943.05; AOAC International, 2000), and minerals (985.01; AOAC International, 2000). Additionally, feed ingredients were analyzed for gross energy (GE) content (Parr 6400 Calorimeter, Parr Instrument Co., Moline, IL) in the nutrition laboratory of the University of Nebraska-Lincoln. The chemical composition of diets and individual feed ingredients are listed in Tables 1 and 2, respectively. For complete AA profile of feedstuffs, samples were analyzed at the Missouri-Columbia Agricultural Experiment Station Chemical Laboratory (Columbia, MO) via cation-exchange chromatography coupled with post-column ninhydrin derivatization with norleucine as internal standard (method 982.30; AOAC International, 2000). Tryptophan was determined after alkaline hydrolysis, and sulfur AA were analyzed after performic acid oxidation (method 988.15; AOAC International, 2000). The AA profiles for corn silage, alfalfa hay, concentrate mix, HFM, and basal TMR are listed in Table 3. Total mixed rations were sampled on $\mathrm{d} 1$ of each collection period and used to determine particle size using the Penn State Particle Separator (Heinrichs and Kononoff, 2002) on an as-is and DM basis $\left(60^{\circ} \mathrm{C}\right.$ for $48 \mathrm{~h}$ ). During each day of the collection period, refusals were sampled and composited on a weight basis. Refusals were analyzed for N, NDF, NDF corrected for ash, starch, ash, and GE via the same methods as feeds.

Total fecal and urine output was collected from each individual cow during the collection period for 4 consecutive days. A $137 \times 76-\mathrm{cm}$ rubber mat was placed behind the cow to aid in fecal collection. Feces were manually collected by personnel $24 \mathrm{~h}$ per day during defecation or occasionally picked up from the rubber mat and deposited into a trash can. Daily feces were subsampled ( $\sim 500$ g as-is), composited on weight basis, and frozen between collection events. After collections, feces were dried at $60^{\circ} \mathrm{C}$ for $48 \mathrm{~h}$ and ground to pass through a 1-mm screen (Wiley Mill, Arthur H. Thomas Co.). The ground fecal samples were analyzed as described for refusals. Total urine was collected by inserting a 30 French Foley catheter into each cow's bladder with a stylus. The balloon was inflated to $55 \mathrm{~mL}$ with physiological saline. The catheter was drained into a 55-L plastic container via Tygon tubing (Saint Gobain, Courbevoie, France). Acid $(50 \% \mathrm{HCl})$ was added to the urine collection container at the beginning of the collection day. Urine $\mathrm{pH}$ was measured at the end of each day, and quantity of acid used was adjusted to maintain a $\mathrm{pH}<5$. Urine was subsampled daily and composited on 
Table 2. Chemical composition of corn silage, alfalfa hay, concentrate mixes, and hydrolyzed feather meal (HFM) used in the current experiment $(\% \text { of } \mathrm{DM})^{1}$

\begin{tabular}{|c|c|c|c|c|c|c|c|c|}
\hline Item $^{2}$ & \multicolumn{2}{|c|}{ Corn silage } & \multicolumn{2}{|c|}{ Alfalfa hay } & \multicolumn{2}{|c|}{ Concentrate } & \multicolumn{2}{|c|}{$\mathrm{HFM}^{3}$} \\
\hline $\mathrm{CP}$ & 8.8 & 0.17 & 19.8 & 0.98 & 23.4 & 0.60 & 89.8 & 2.22 \\
\hline $\mathrm{ADF}$ & 23.3 & 4.38 & 36.1 & 2.34 & 16.2 & 0.85 & ${ }^{4}$ & - \\
\hline NDF & 36.9 & 4.11 & 43.4 & 3.35 & 24.5 & 1.83 & - & - \\
\hline $\mathrm{NDF}_{\mathrm{OM}}$ & 36.1 & 4.21 & 42.7 & 3.46 & 24.0 & 1.71 & - & - \\
\hline Lignin & 3.05 & 0.53 & 8.09 & 0.29 & 2.98 & 0.83 & - & - \\
\hline Sugar & 1.15 & 0.75 & 5.23 & 0.96 & 8.38 & 0.33 & - & - \\
\hline Starch & 37.4 & 4.83 & 1.8 & 0.25 & 25.4 & 2.86 & - & - \\
\hline Crude fat & 3.08 & 0.49 & 1.80 & 0.29 & 8.36 & 1.10 & 8.95 & 1.71 \\
\hline Ash & 5.21 & 0.14 & 10.6 & 0.18 & 9.17 & 0.56 & 2.40 & 0.63 \\
\hline $\mathrm{Ca}$ & 0.26 & 0.05 & 1.16 & 0.10 & 1.56 & 0.12 & 0.52 & 0.22 \\
\hline $\mathrm{P}$ & 0.24 & 0.06 & 0.34 & 0.03 & 0.44 & 0.05 & 0.28 & 0.13 \\
\hline
\end{tabular}

${ }^{1} \mathrm{n}=4$ for corn silage, alfalfa hay, and concentrate; $\mathrm{n}=3$ for HFM.

${ }^{2} \mathrm{NDF}_{\mathrm{OM}}=\mathrm{NDF}$ corrected for ash; ADICP $=$ acid detergent insoluble CP; NDICP $=$ neutral detergent insoluble CP.

${ }^{3}$ Hydrolyzed feather meal blend from 3 sources (33.3\% American Proteins Inc., Cumming, GA; 18.6\% Pilgrim's, Greeley, CO; 48.1\% Simmons Foods, Siloam Springs, AR); $67.8 \pm 9.18 \%$ RUP (16-h rumen in situ incubation) with RUP digestibility of $64.7 \pm 8.97 \%$ (mobile bag technique). Mean and SD weighted based on the inclusion of each source.

${ }^{4}$ Not determined.

a wet weight basis. Urine samples were frozen $\left(-20^{\circ} \mathrm{C}\right)$ until analysis for $\mathrm{GE}$ and $\mathrm{N}$ as described above. Urine GE was determined by drying $\left(60^{\circ} \mathrm{C}\right)$ approximately 4
$\mathrm{mL}$ of sample in a bomb capsule until dry $(4 \mathrm{~h})$ and then combusting the sample (Parr 6400 Calorimeter, Parr Instrument Co.). Urine $\mathrm{N}$ of liquid sample was

Table 3. Concentration of AA in the basal diet, corn silage, alfalfa hay, concentrate mix, and hydrolyzed feather meal (HFM) used in the current experiment $(\% \text { of } \mathrm{CP})^{1}$

\begin{tabular}{|c|c|c|c|c|c|c|c|c|c|c|}
\hline \multirow[b]{2}{*}{ Item } & \multicolumn{2}{|c|}{ Basal TMR } & \multicolumn{2}{|c|}{ Corn silage } & \multicolumn{2}{|c|}{ Alfalfa hay } & \multicolumn{2}{|c|}{ Concentrate } & \multicolumn{2}{|c|}{$\mathrm{HFM}^{2}$} \\
\hline & Mean & SD & Mean & SD & Mean & SD & Mean & SD & Mean & SD \\
\hline \multicolumn{11}{|l|}{ EAA } \\
\hline Arg & 3.78 & 0.34 & 1.75 & 0.15 & 3.54 & 0.14 & 4.99 & 0.08 & 6.91 & 0.16 \\
\hline His & 1.52 & 0.07 & 1.49 & 0.11 & 1.71 & 0.11 & 1.45 & 0.07 & 1.13 & 0.20 \\
\hline Ile & 3.59 & 0.11 & 3.33 & 0.09 & 3.90 & 0.05 & 3.66 & 0.09 & 4.84 & 0.02 \\
\hline Leu & 6.93 & 0.23 & 8.12 & 0.10 & 6.39 & 0.13 & 6.80 & 0.24 & 7.98 & 0.08 \\
\hline Phe & 3.88 & 0.19 & 3.50 & 0.31 & 4.28 & 0.08 & 3.91 & 0.10 & 4.92 & 0.18 \\
\hline Thr & 3.30 & 0.06 & 3.07 & 0.16 & 3.73 & 0.06 & 3.36 & 0.07 & 4.57 & 0.02 \\
\hline $\operatorname{Trp}$ & 0.50 & 0.05 & 0.34 & 0.01 & 0.80 & 0.04 & 0.48 & 0.03 & 0.50 & 0.06 \\
\hline Val & 4.91 & 0.17 & 4.47 & 0.09 & 4.99 & 0.08 & 5.27 & 0.13 & 7.60 & 0.39 \\
\hline \multicolumn{11}{|c|}{ NEAA } \\
\hline Ala & 5.20 & 0.50 & 8.52 & 0.63 & 4.66 & 0.10 & 4.07 & 0.10 & 4.54 & 0.08 \\
\hline Asp & 6.86 & 0.55 & 4.45 & 0.43 & 10.4 & 0.49 & 6.44 & 0.12 & 6.72 & 0.10 \\
\hline Tau & 1.31 & 0.11 & 2.21 & 0.10 & 1.01 & 0.11 & 1.02 & 0.06 & 0.03 & 0.01 \\
\hline Tyr & 2.14 & 0.07 & 1.49 & 0.15 & 1.95 & 0.03 & 2.51 & 0.02 & 2.65 & 0.30 \\
\hline
\end{tabular}

${ }^{1} \mathrm{n}=4$ for basal TMR, corn silage, alfalfa hay and concentrate; $\mathrm{n}=3$ for HFM.

${ }^{2}$ Hydrolyzed feather meal blend from 3 sources (33.3\% American Proteins Inc., Cumming, GA; 18.6\% Pilgrim's, Greeley, CO; 48.1\% Simmons Foods, Siloam Springs, AR). Mean and SD weighted based on the inclusion of each source. 
determined by Cumberland Valley Analytical Services Inc., using a Leco FP-528 N Combustion Analyzer (Leco Corp.).

Milk production was measured daily, and milk samples were collected during both the morning and evening milkings of the collection periods. Milk from individual milkings was preserved with 2-bromo-2-nitropropane-1,3 diol and sent to Heart of America DHIA (Kansas City, MO). Milk samples were analyzed for fat, protein, lactose, SNF, MUN, and SCC using a Bentley FTS/FCM Infrared Analyzer (Bentley Instruments, Chaska, MN). Additionally, milk from each milking event was composited on a weight basis. Composited milk samples were analyzed for GE and $\mathrm{N}$ as described previously for urine.

Blood samples were collected into evacuated $\mathrm{K}_{2}$ EDTA tubes from the tail vessel approximately $3 \mathrm{~h}$ after feeding during $2 \mathrm{~d}$ within collection week when cows were not in a headbox. Day of blood sampling was randomized with respect to treatment. One blood sample was analyzed for hemoglobin concentration using a Siemens Advia 2120 (Siemens Healthineers, Erlangen, Germany). For the second blood sample, plasma was immediately separated by centrifugation at $1,500 \times g$ at $4^{\circ} \mathrm{C}$ for 20 min. An aliquot of $3 \mathrm{~mL}$ of plasma was deproteinized with $15 \%$ sulfosalicylic acid (4 parts plasma to 1 part $15 \%$ sulfosalicylic acid). Samples were then placed in an ice bath for $10 \mathrm{~min}$ before centrifuging at 1,500 $\times$ $g$ at $4^{\circ} \mathrm{C}$ for $20 \mathrm{~min}$. The supernatant was collected, and $0.75-\mathrm{mL}$ aliquots were placed into Nunc CryoTube vials (Nalge Nunc International, Roskilde, Denmark) and stored at $-80^{\circ} \mathrm{C}$. Blood samples collected on the second day were processed the same way and added to CryoTube vials. Plasma samples were submitted to the University of Missouri-Columbia Agricultural Experiment Station Chemical Laboratory for analysis of free AA, urea, carnosine, and 3-methylhistidine (Deyl et al., 1986; Fekkes, 1996). Plasma AA concentrations were adjusted for the use of $15 \%$ sulfosalicylic acid.

Heat production was determined through the headbox-type indirect calorimeters as described previously (Freetly et al., 2006; Foth et al., 2015). For each cow, a collection period of $23 \mathrm{~h}$ was used to measure $\mathrm{O}_{2}$ consumption and $\mathrm{CO}_{2}$ and $\mathrm{CH}_{4}$ production. Gas data were adjusted to a 24 -h period. Four headboxes were used, and data were collected across $3 \mathrm{~d}$ during the 4-d collection period. Cows were adapted to headboxes for a minimum of $3 \mathrm{~d}$ before the start of the experiment. Feed was placed in the bottom of the headbox, and cows were allowed ad libitum access to water from a water bowl placed inside the headbox. Free water intake was measured using a water meter (Model DLJSJ75, Daniel L. Jerman Co., Hackensack, NJ) while each cow was inside the headbox. Within the headbox, temperature and dew point were measured every minute during the 23-h collection interval using a probe (Model TRH-100, Pace Scientific Inc., Moorseville, NC) and recorded using a data logger (Model XR440, Pace Scientific Inc.). Line pressure was measured using a u-tube manometer (Item no. 1221-8, Park Supply of America Inc., Minneapolis, MN), and barometric pressure of the room was measured using a barometer (Chaney Instruments Co., Lake Geneva, WI). Total volume of gas flow through the headbox was measured using a gas meter (Model AL425, American Meter, Horsham, PA) and corrected to standard temperature and pressure $\left(0^{\circ} \mathrm{C}, 101.3\right.$ $\mathrm{kPa}$ ) with adjustment for moisture content of exhaust air (Nienaber and Maddy, 1985). From the headbox, continuous samples of incoming and outgoing air were collected into separate bags (44 L, LAM-JAPCONNSE, Pollution Measurement Corp., Oak Park, IL) using glass tube rotameters (Model 1350E Sho-Rate 50, Brooks Instruments, Hatfield, PA). Gas bags were analyzed for $\mathrm{O}_{2}, \mathrm{CO}_{2}$, and $\mathrm{CH}_{4}$ using an Emerson X-stream 3-channel analyzer (Emerson, Solon, $\mathrm{OH}$ ) according to the method of Nienaber and Maddy (1985). System efficiency (headbox and gas analyzer) was determined by burning 100\% ethyl alcohol and measuring gas recoveries. Recoveries of $\mathrm{O}_{2}$ and $\mathrm{CO}_{2}$ were (average $\pm \mathrm{SD}$ ) 90 \pm 4.2 and $89 \pm 4.5 \%$, respectively. Gas measurements were adjusted to $100 \%$ using recoveries for individual headboxes.

\section{Energy Calculations}

The respiratory quotient was calculated using the ratio of $\mathrm{CO}_{2}$ produced to $\mathrm{O}_{2}$ consumed (L/L). Methane energy was estimated by multiplying $\mathrm{CH}_{4}$ production by its enthalpy $(9.45 \mathrm{kcal} / \mathrm{L})$. Calculations for digested energy (DE) and ME were as follows:

$$
\begin{gathered}
\text { DE }(\text { Mcal } / d)=\text { GE }(\text { Mcal } / d) \\
- \text { fecal energy }(\text { Mcal } / d) ; \\
\operatorname{ME}(\text { Mcal } / d)=\text { DE }(\text { Mcal } / d) \\
- \text { urine energy }(\text { Mcal } / d)-\text { methane energy }(\text { Mcal } / d) .
\end{gathered}
$$

Unaccounted-for energy was assumed to represent tissue energy retention or mobilization, which was corrected to an $\mathrm{NE}_{\mathrm{L}}$ basis as follows:

$$
\begin{gathered}
\text { Residual energy }(\mathrm{Mcal} / \mathrm{d})=\mathrm{ME}(\mathrm{Mcal} / \mathrm{d}) \\
- \text { heat production }(\mathrm{Mcal} / \mathrm{d})-\text { milk energy }(\mathrm{Mcal} / \mathrm{d}) \text {; }
\end{gathered}
$$


Tissue energy $\left(\right.$ Mcal of $\left.\mathrm{NE}_{\mathrm{L}} / \mathrm{d}\right)=$

positive residual energy

$\times \mathrm{k}_{\mathrm{T}}$ or negative residual energy $\times \mathrm{k}_{\mathrm{G}} / \mathrm{k}_{\mathrm{L}}$,

where $\mathrm{k}_{\mathrm{T}}$ is the efficiency of utilizing body reserve energy for milk production, $\mathrm{k}_{\mathrm{G}}$ is the efficiency of utilizing ME intake for tissue gain, and $\mathrm{k}_{\mathrm{L}}$ is the efficiency of utilizing ME intake for milk production. Values of 0.89 , 0.75 , and 0.66 were used for $\mathrm{k}_{\mathrm{T}}, \mathrm{k}_{\mathrm{G}}$, and $\mathrm{k}_{\mathrm{L}}$, respectively (Moraes et al., 2015).

\section{Statistical Analysis}

Data were analyzed in R (v. 3.5.1, R Foundation for Statistical Computing, Vienna, Austria) using the lmer (Kuznetsova et al., 2017) package. Models were developed a priori and included the fixed effects of Lys and His level and interaction of Lys and His, and the random effect of period, square, and cow nested in square. A type-III ANOVA with Kenward-Roger denominator degrees of freedom was completed using the anova function of R. All data are presented as least squares means \pm largest standard error. Significance and trends were declared at $P \leq 0.05$ and $P \leq 0.10$, respectively.

\section{RESULTS AND DISCUSSION}

This experiment was designed to test the effects of RP Lys and RP His alone or in combination on milk production and composition, $\mathrm{N}$ and energy utilization, and AA status when feeding a base diet containing HFM. In our previous work, we observed a linear decrease in milk protein with increasing inclusion of HFM (Morris et al., 2020). Because HFM is low in Lys and His (NRC, 2001), the current experiment was designed to determine whether Lys, His, or both, are limiting in diets containing HFM. Most previous studies designed to test RP Lys and RP His have looked at the effects of supplementing these AA individually (Giallongo et al., 2016; Zang et al., 2019) or in combination with Met (Lee et al., 2012; Giallongo et al., 2016). The current experiment differs because it was designed to examine the interaction between supply of Lys and His.

Upon initiation of the study, it was assumed that no cows had been previously bred, but breeding synchronization during the third period caused a late-term iatrogenic abortion in one cow. All data from this cow were removed before statistical analysis. During period 1, one cow (on treatment LYSOHIS0) refused to eat normally while in the headbox, resulting in lower DMI compared with when she was out of the headbox (11.0 vs. $19.6 \mathrm{~kg} / \mathrm{d}$ ). This led to gas consumption and production measurements that were 22 to $32 \%$ below the mean of other cows during this period. However, this was on $\mathrm{d} 4$ of the collection period; thus, data from the first $3 \mathrm{~d}$ of collection were used, and only gas-related variables were not calculated. Another cow became ill during period 4 (pneumonia, on treatment LYSOHIS+), and data for this period were removed before statistical analysis. Therefore, 42 out of 48 possible data points were used for gas-related energy calculations, and 43 out of 48 were used for all other variables.

The HFM used in the current study is representative of that available commercially. The HFM was 89.8 $\pm 2.2 \% \mathrm{CP}$ and $67.8 \pm 9.2 \% \mathrm{RUP}$, and digestibility of RUP was $64.7 \pm 9.0 \%$. In a recent study using 10 HFM from different sources, the CP, RUP, and RUP digestibility were $90.7 \pm 2.86 \%, 77.8 \pm 7.8 \%$, and 61.1 $\pm 9.1 \%$, respectively (Buse et al., 2019). The RUP content of the blend of HFM used in the current study is similar to other bypass protein sources such as blood meal and expellers soybean meal (63 to 70\% RUP); however, the digestibility of the RUP is much lower compared with the same bypass protein sources (88 to 99\%; Paz et al., 2014). The Lys and His contents of the HFM were 2.37 and $1.13 \%$ of $\mathrm{CP}$, respectively (Table $3)$. The Lys content of HFM is similar to that of corn and corn byproducts (2.2 to $2.8 \%$ of $\mathrm{CP}$ ) but lower than those of soybean products (5.8 to $6.3 \%$ of $\mathrm{CP}$ ) and blood meal (9.0\% of CP; NRC, 2001). The His content of HFM is lower than that of soybean products (2.4 to $2.8 \%$ of CP), corn and corn byproducts (2.5 to $3.1 \%$ of CP), and blood meal (6.8\% of CP; NRC, 2001). Additionally, compared with target AA content of MP, microbial protein has a high Lys content $(8.1 \%$ of total AA) and low His content (1.9\% of total AA; Sok et al., 2017). Because of the low His content, HFM may be a poor complementary protein source for microbial protein.

In previous studies where the effects of RP AA were tested, diets were commonly formulated to be deficient in MP and to have a low supply of the AA of interest, and RP AA are supplemented to bring the AA supply to target contents (Lee et al., 2012; Giallongo et al., 2016; Zang et al., 2019). To prevent inadequate supply of AA besides Lys or His, we initially formulated a diet (NRC 2001) to be adequate in MP $(+16 \mathrm{~g} / \mathrm{d})$ under the following assumptions: $19.5 \mathrm{~kg} / \mathrm{d}$ of DMI, $27.0 \mathrm{~kg} / \mathrm{d}$ of milk yield, $5.00 \%$ milk fat, and $3.35 \%$ milk true protein. However, predicting animal performance a priori is challenging, and throughout our study, MP balance was on average $123 \mathrm{~g} / \mathrm{d}$ (Table 4) due to lower-thanexpected milk and milk protein yields. We targeted Lys and His supplies of 6.6 (Schwab et al., 2005) and 2.2\% (Lee et al., 2012) of MP, respectively. The increased supply of MP resulted in estimated digestible AA supplies that were only slightly below targets $(-4$ to -2 
$\mathrm{g} / \mathrm{d}$ ) in the treatments supplemented with non-RP AA. The RP Lys used in the current study was $44.5 \%$ Lys and $80.3 \pm 5.31 \%$ RUP, with RUP digestibility of 95.8 $\pm 1.23 \%$. Therefore, $70 \mathrm{~g}$ of RP Lys was estimated to supply $24 \mathrm{~g}$ of digestible Lys. The RP His was $43.2 \%$ His and $57.4 \pm 3.02 \%$ RUP, with RUP digestibility of $92.4 \pm 3.67 \%$. Therefore, $32 \mathrm{~g}$ of RP His was estimated to supply $7 \mathrm{~g}$ of digestible His. When RP Lys and His were supplemented, supply exceeded targets by 20 to 22 and 4 to $5 \mathrm{~g} / \mathrm{d}$ for Lys and His, respectively. Because the supply of Lys and His in the basal diets were only marginally below targets, it is plausible that supplies of Lys and His may have been adequate without the inclusion of either RP Lys or His. Variance in modelestimated supply of individual AA can be large (Fleming et al., 2019b); therefore, the true supply of Lys and His in the current study is unknown. Admittedly, the target for Lys and His supply are not well established, and suppling increasing amounts of Lys (Vyas and Erdman, 2009) or His (Zang et al., 2019) may increase milk production and milk component yield.

\section{Plasma AA, Hemoglobin, Carnosine, and 3-Methylhistidine}

Plasma AA concentration may serve as a gross indicator of the metabolic status of these AA. In the cur- rent study, an interaction between RP Lys and RP His was observed for plasma Lys concentration (interaction $P=0.04$; Table 5). Specifically, supplementing RP Lys increased plasma concentration of Lys without RP His (77.7 vs. $66.0 \pm 4.69 \mu M$ ); however, when RP His was supplemented, RP Lys decreased plasma concentration of Lys (71.4 vs. $75.0 \pm 4.69 \mu M)$. It is generally understood that plasma AA concentrations are affected by plane of nutrition, stage of lactation, proportion of MP from microbial protein, and milk protein yield; thus, plasma AA concentration may not always reflect changes in the duodenal supply of AA (Patton et al., 2015; Martineau et al., 2017). Others have observed increased plasma Lys and His when supplementing the same RP AA products used in this study (Lee et al., 2012; Giallongo et al., 2016). In a meta-regression, plasma Lys concentration was quadratically related to supply of metabolizable Lys, such that with increasing metabolizable Lys supply, plasma Lys concentration increased and then plateaued (Martineau et al., 2019). In the current study, decreased plasma Lys with RP Lys when RP His was supplemented may be due to increased milk protein yield and increased protein accretion, as indicated by increased $\mathrm{N}$ balance (see later discussion). Milk protein yield is negatively related to plasma Lys (Patton et al., 2015). Increased plasma Lys when RP Lys was supplemented and RP His was not

Table 4. Estimated dietary net energy and MP and AA balance in lactating Jersey cows fed a diet containing $5 \%$ hydrolyzed feather meal and supplemented with rumen-protected (RP) Lys and His ${ }^{1}$

\begin{tabular}{|c|c|c|c|c|}
\hline \multirow[b]{3}{*}{ Item } & \multicolumn{4}{|c|}{ Treatment $^{2}$} \\
\hline & \multicolumn{2}{|c|}{ LYSO } & \multicolumn{2}{|c|}{$\mathrm{LYS}+$} \\
\hline & HIS0 & HIS + & HIS0 & HIS + \\
\hline $\mathrm{NE}_{\mathrm{L}}, \mathrm{Mcal} / \mathrm{kg}$ & 1.64 & 1.63 & 1.64 & 1.63 \\
\hline \multicolumn{5}{|l|}{$\mathrm{MP}, \mathrm{g} / \mathrm{d}$} \\
\hline Required & 1,822 & 1,856 & 1,809 & 1,885 \\
\hline Supply & 1,958 & 1,958 & 1,946 & 2,000 \\
\hline Balance & 136 & 102 & 137 & 115 \\
\hline \multicolumn{5}{|l|}{ dLys, $g / d^{3}$} \\
\hline Target & 120 & 122 & 119 & 124 \\
\hline Supply from dietary and microbial protein & 118 & 118 & 117 & 120 \\
\hline Supply from RP Lys ${ }^{4}$ & 0 & 0 & 24 & 24 \\
\hline Balance & -2 & -4 & 22 & 20 \\
\hline \multicolumn{5}{|l|}{ dHis, $\mathrm{g} / \mathrm{d}$} \\
\hline Target & 40 & 41 & 40 & 41 \\
\hline Supply from dietary and microbial protein & 38 & 38 & 38 & 39 \\
\hline Supply from RP His ${ }^{5}$ & 0 & 7 & 0 & 7 \\
\hline Balance & -2 & 4 & -2 & 5 \\
\hline
\end{tabular}

${ }^{1}$ All values estimated from NRC (2001) using mean production and measured feed composition.

${ }^{2} \mathrm{LYS} 0=0 \mathrm{~g} / \mathrm{d}$ of RP Lys; LYS $+=70 \mathrm{~g} / \mathrm{d}$ of RP Lys; HIS0 $=0 \mathrm{~g} / \mathrm{d}$ of RP His; HIS $+=32 \mathrm{~g} / \mathrm{d}$ of RP His.

${ }^{3}$ Targets for digestible Lys (dLys) and digestible His (dHis) were calculated as 6.6\% (Schwab et al., 2005) and $2.2 \%$ (Lee et al., 2012), respectively, of MP requirements.

${ }^{4} 80.3 \pm 5.31 \%$ rumen bypass with a $95.8 \pm 1.23$ intestinal digestibility as determined using the mobile bag technique (Paz et al., 2014).

${ }^{5} 57.4 \pm 3.02 \%$ rumen bypass with a $92.4 \pm 3.67$ intestinal digestibility as determined using the mobile bag technique (Paz et al., 2014). 
Table 5. Plasma concentration $(\mu M)$ of AA, urea, hemoglobin, carnosine, and 3-methylhistitidine of lactating Jersey cows fed a diet containing $5 \%$ hydrolyzed feather meal and supplemented with rumen-protected (RP) Lys and His

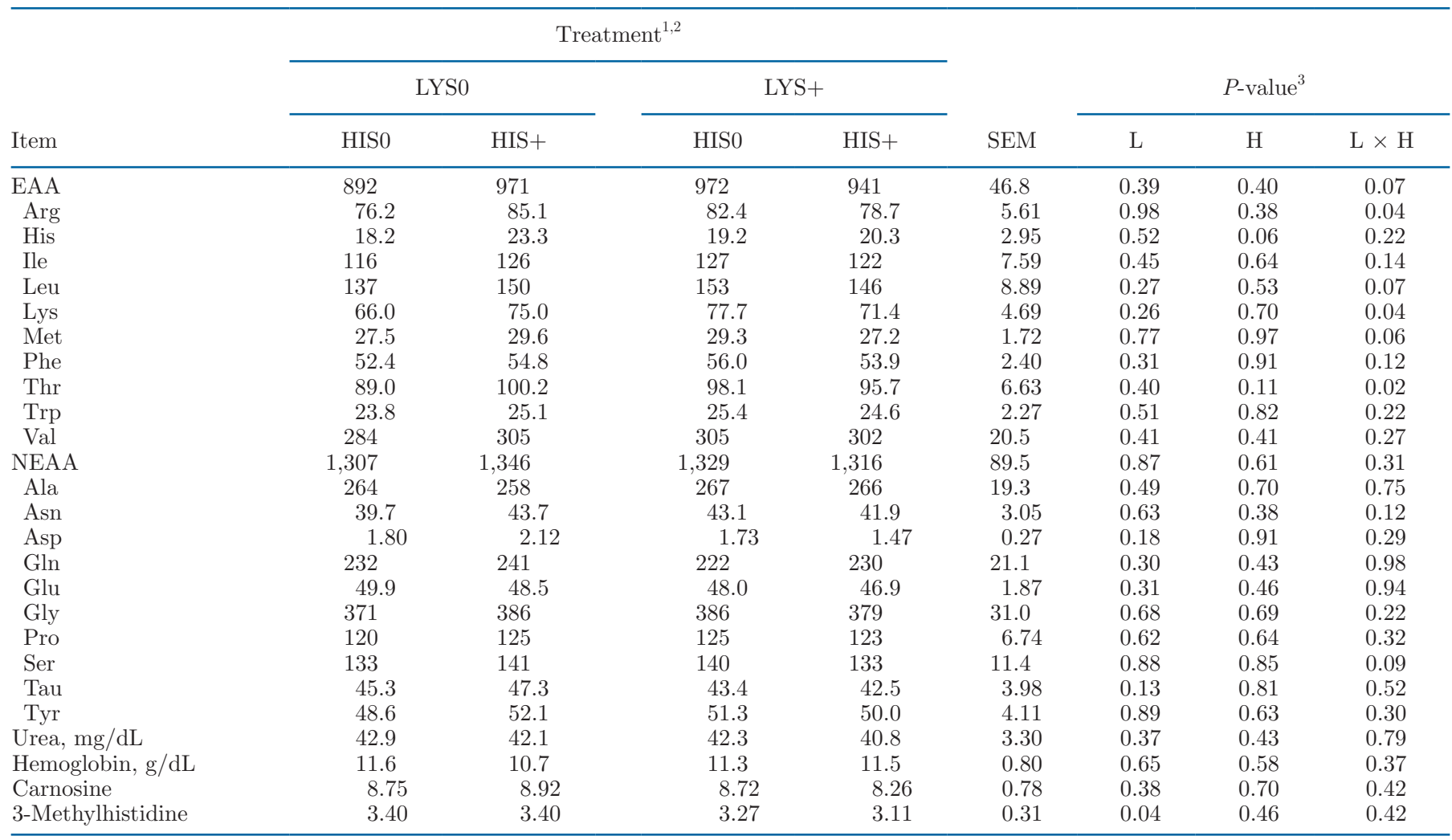

${ }^{1} \mathrm{LYS} 0=0 \mathrm{~g} / \mathrm{d}$ of RP Lys; LYS $+=70 \mathrm{~g} / \mathrm{d}$ of RP Lys; HIS0 $=0 \mathrm{~g} / \mathrm{d}$ of RP His; HIS $+=32 \mathrm{~g} / \mathrm{d}$ of RP His; $\mathrm{n}=43$ for all variables.

${ }^{2} \mathrm{LSM}$; largest $\mathrm{SE}$ of treatment mean is listed.

${ }^{3} \mathrm{~L}=$ main effect of Lys supply; $\mathrm{H}=$ main effect of His supply; $\mathrm{L} \times \mathrm{H}=$ interaction between Lys and His.

supplemented, and increased plasma His when RP His was supplemented, indicates adequate rumen protection and intestinal digestibility for the RP AA products used in the current experiment.

Histidine is unique among EAA, in that a labile pool exists in carnosine ( $\beta$-alanyl-l-His), anserine ( $\beta$-alanyl$\mathrm{N}$-methyl-His), and blood hemoglobin, and this pool may be mobilized to cover deficiencies in the short term (Lapierre et al., 2008). In the current experiment, RP His did not affect $(P>0.58)$ plasma carnosine and hemoglobin concentration. In a His-deficient diet, plasma carnosine and hemoglobin concentration were decreased; however, plasma hemoglobin was not decreased by a low-His diet until the fifth week on experimental diets (Giallongo et al., 2017). Thus, the duration of the current experiment, $4 \mathrm{wk}$, may not have been long enough for changes in carnosine and hemoglobin status to occur. Increased plasma carnosine with increased His supply has been observed (Zang et al., 2019), but not in all studies (Lee et al., 2012; Giallongo et al., 2015). The reason for this discrepancy is not clear, and we suggest that future research seek to further describe the labile pools of His and may need to test the effects of His supply on His status in continuous experiments that are at least $5 \mathrm{wk}$ in duration.

Supplementing RP Lys decreased $(P=0.04) 3$-methylhistidine $(3.19$ vs. $3.40 \pm 0.31 \mu M)$. In the current experiment, the cause for decreased 3-methyhistidien with increased Lys supply is unknown and may suggest that muscle breakdown was decreased with increased Lys supply. 3-methylhistidine is formed from the methylation of His, and muscle breakdown is the primary source of circulating 3-methylhistidine (Harris, 1981). Thus, 3-methylhistidine may serve as a biomarker for muscle breakdown (Akamatsu et al., 2007). Appuhamy et al. (2011) observed an increase in 3-methylhistidine with jugular infusion of Met, Lys, and branched-chain AA. These authors suggested that increased milk protein synthesis with supplemental AA treatments may have been supported by AA mobilization from muscle.

Similar to plasma Lys, interactions $(P<0.07)$ were observed for plasma concentration of EAA, Arg, Leu, Met, and Thr. The cause of this interaction is unknown but may be due to an increase in utilization of these AA by mammary glands and peripheral tissue when both RP Lys and His were supplemented. Supplement- 
ing RP His tended to increase milk protein yield, and supplementing RP Lys tended to increase $\mathrm{N}$ balance (see later discussion) and decreased 3-methylhistidine, which suggests an increase in protein accretion and decrease in protein mobilization from muscle. In other experiments where His or Lys were supplemented, in general, plasma concentration of non-supplemented EAA were not affected (Lee et al., 2012; Paz and Kononoff, 2014; Zang et al., 2019). However, plasma Leu concentration decreased with jugular infusion of Met and Lys (Appuhamy et al., 2011), and with jugular infusion of Met, Lys, and His, plasma concentration of non-supplemented EAA, Leu, and Thr decreased (Yoder et al., 2020). A third EAA may have become limiting when both RP Lys and His were supplemented.

\section{DMI, Milk Yield, and Milk Composition}

Quantification of the effects of individual AA supply on milk protein yield is needed to advance our understanding of AA requirements and to allow nutritionists to formulate diets that minimize $\mathrm{CP}$ while maximizing the efficiency of AA utilization for milk protein synthesis. In the current study, supplementation of RP Lys had no effect $(P>0.14)$ on DMI, milk yield, or milk composition (Table 6). Milk protein synthesis is one of the primary roles of plasma Lys (Schwab et al., 2005; Manjarin et al., 2014). Additionally, uptake of Lys in the mammary glands exceeds secretion in milk protein due to the utilization of Lys in the mammary glands for NEAA synthesis, which appears to be obligate (Lapierre et al., 2009). In support of this notion, even when Lys was removed from an abomasal infusion, uptake of Lys in the mammary glands still exceeded Lys output in milk, due to the utilization of Lys for NEAA synthesis (Lapierre et al., 2009). This highlights the importance of adequate Lys supply to support milk protein synthesis. We hypothesized that increasing supply of Lys would increase milk protein yield. Although our results contradict this hypothesis, others have observed a lack of response to increased supply of Lys. In a meta-analysis, Robinson (2010) reported that supplementing RP Lys compared with control diets had no effect of milk composition. In an individual study, supplementing RP Lys in an MP-deficient diet increased milk protein composition by 0.09 percentage units, but milk protein yield was similar (Giallongo et al., 2016). We speculate that the observed lack of response to Lys with or without increased His supply may have occurred due to one or a combination of the following: (1) Lys supply may not have been limiting in the basal diet; (2) increased supply of Lys from the RP Lys in the current study may not have been enough to elicit a response; (3) His supply in the RP His treatment may have still been limiting; (4) a third EAA may have been limiting; or (5) increasing supply of Lys has minimal to no effect on milk production and composition. Further investigation is warranted, wherein RP

Table 6. DMI, milk production and milk composition, free water intake, BW, and BCS of lactating Jersey cows fed a diet containing $5 \%$ hydrolyzed feather meal and supplemented with rumen-protected (RP) Lys and His

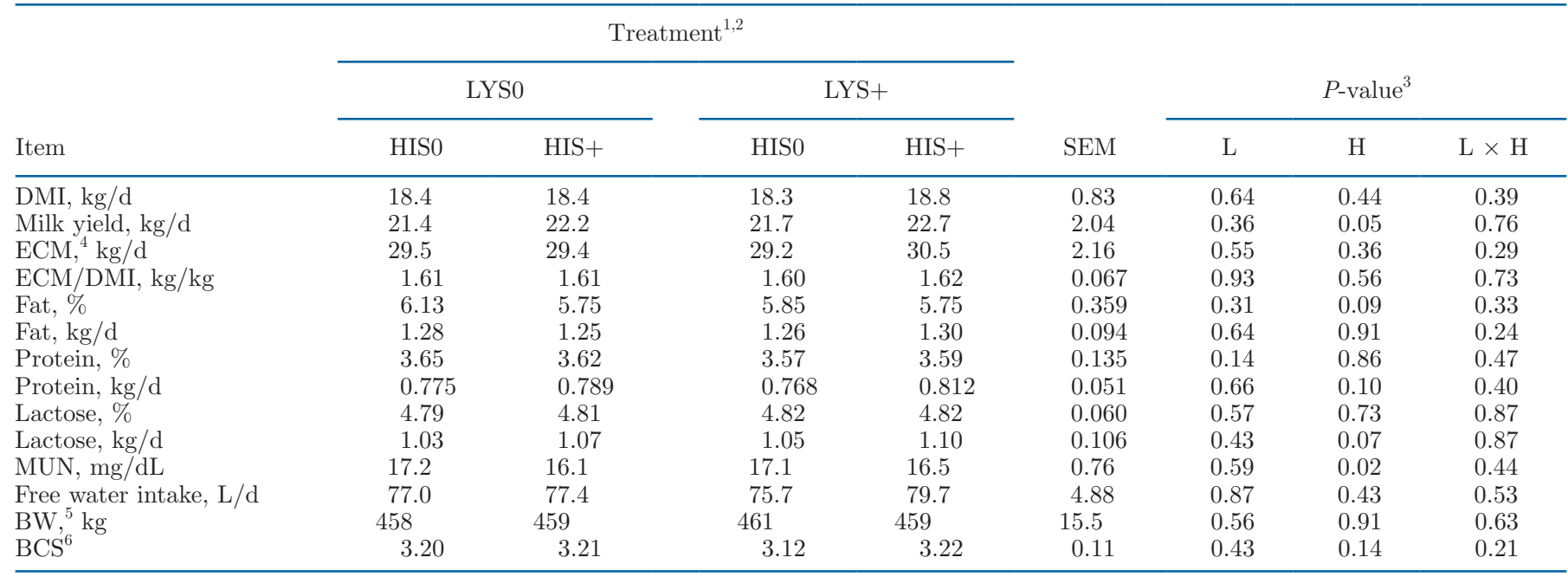

${ }^{1} \mathrm{LYS} 0=0 \mathrm{~g} / \mathrm{d}$ of RP Lys; LYS $+=70 \mathrm{~g} / \mathrm{d}$ of RP Lys; HIS0 $=0 \mathrm{~g} / \mathrm{d}$ of RP His; HIS $+=32 \mathrm{~g} / \mathrm{d}$ of RP His; $\mathrm{n}=43$ for all variables.

${ }^{2} \mathrm{LSM}$; largest SE of treatment mean is listed.

${ }^{3} \mathrm{~L}=$ main effect of Lys supply; $\mathrm{H}=$ main effect of His supply; $\mathrm{L} \times \mathrm{H}=$ interaction between Lys and His.

${ }^{4} \mathrm{ECM}=0.327 \times$ milk yield $(\mathrm{kg})+12.95 \times$ fat $(\mathrm{kg})+7.20 \times$ true protein $(\mathrm{kg})$ (Tyrrell and Reid, 1965).

${ }^{5}$ Average from 2 measurements during last $4 \mathrm{~d}$ of each period.

${ }^{6} \mathrm{Scored} 1$ to 5 (thin to fat) by 2 independent observations. 
Lys is incrementally supplemented to diets in which Lys supply is low and tested in conjunction with other potentially limiting AA, such as His.

Histidine status may be involved in the regulation of feed intake via the central nervous system, and increased His status may have a positive effect on feed intake (Giallongo et al., 2015). Several studies have observed increased DMI with RP His or abomasal His infusion (Vanhatalo et al., 1999; Giallongo et al., 2015, 2016). However, in the current feeding study, RP His did not affect $(P=0.44)$ DMI. Because endogenous pools of His can be mobilized to increase His status in the short term (Lapierre et al., 2012), decreased DMI due to a His deficiency may have been prevented in the short term in cows fed diets without RP His. Giallongo et al. (2017) observed that the low-His diet did not affect DMI during the first 2 wk of the experiment, but decreased DMI from wk 5 to 10 of the experiment.

Supplementing RP His increased $(P=0.05)$ milk yield $(22.5$ vs. $21.6 \pm 2.04 \mathrm{~kg} / \mathrm{d})$ and tended $(P<0.10)$ to increase milk protein yield (0.801 vs. $0.772 \pm 0.051$ $\mathrm{kg} / \mathrm{d}$ ) and milk lactose yield (1.09 vs $1.04 \pm 0.106 \mathrm{~kg} / \mathrm{d}$ ), whereas the concentration of milk fat tended $(P=0.09)$ to decrease ( 5.75 vs. $5.99 \pm 0.359 \%)$. Because milk fat yield was not affected $(P=0.91)$ by RP His (averaging $1.27 \pm 0.094 \mathrm{~kg} / \mathrm{d}$ ), the decreased milk fat concentration was likely a dilution effect caused by increased milk yield. Consistent with the increased milk protein production in the current study, several individual studies have observed similar responses with abomasal infusion of His (Vanhatalo et al., 1999; Huhtanen et al., 2002) or by feeding RP His (Giallongo et al., 2015; Zang et al., 2019). Furthermore, RP His decreased ( $P$ $=0.02) \mathrm{MUN}(16.3$ vs. $17.2 \pm 0.76 \mathrm{mg} / \mathrm{dL}$ ), which suggests that decreased whole-body catabolism of AA may have occurred in response to increased incorporation of AA into milk protein. In the study by Giallongo et al. (2016), the addition of RP His increased milk protein concentration but did not affect milk protein yield; however, when RP His was fed in combination with RP Met and RP Lys, milk protein concentration and yield increased. This suggests that supply of other EAA may have limited the response to individual addition of AA, thus demonstrating the importance of adequate supply of individual AA to support milk protein production.

\section{Gas Consumption and Production, Energy Utilization, Nutrient Digestibility, and Nitrogen Utilization}

To assess the effects of the use of the headboxes on feeding behavior, we compared DMI when cows were in the headboxes to when cows were out of the headboxes. When cows were in the headboxes, DMI decreased
$(P<0.01)$ compared with when cows were not in the headboxes (17.6 vs. $18.6 \pm 0.65 \mathrm{~kg} / \mathrm{d}$; data not shown). This effect was consistent across treatments; thus, differences between treatment effects for energy partitioning may be interpreted with confidence. Although we strive to make animals comfortable and familiar with headboxes, a slight reduction in DMI was not unexpected (Morris et al., 2020). However, DMI was still within normal ranges, and we are unaware of alternative techniques that would allow us to make the measures described herein.

We expected to observe differences in energy utilization due to increased milk protein yield with supplemental Lys and His. Specifically, we expected to see increased milk energy output with supplemental AA. Supplementing RP Lys increased $(P<0.01)$ efficiency of converting DE into $\mathrm{ME}(0.885$ vs. $0.878 \pm 0.006)$, which was due to a tendency for decreased $(P=0.06)$ $\mathrm{CH}_{4}$ energy (3.95 vs. $4.24 \pm 0.27 \mathrm{Mcal} / \mathrm{d}$; Table 7). Decreased $\mathrm{CH}_{4}$ with RP Lys was not expected, and the cause is unknown. The RP Lys was lipid-coated, and fat is often associated with decreased $\mathrm{CH}_{4}$ production (Appuhamy et al., 2016). However, the RP Lys only increased fat intake by $35 \mathrm{~g} / \mathrm{d}$ (approximately $0.2 \%$ of diet DM), which should not have had a large effect on $\mathrm{CH}_{4}$ production. Treatment did not affect $(P>0.14)$ any other measures of energy utilization.

Although tendencies for differences $(P<0.10)$ in nutrient digestibility were observed when supplementing RP Lys (Table 8), the magnitude of responses were small and did not result in a difference in energy digestibility or milk production and composition; thus, differences in nutrient digestibility with RP Lys may not be biologically important or may not be large enough to cause differences in production. Several studies observed increased DMI with RP His or with abomasal His infusion (Vanhatalo et al., 1999; Giallongo et al., 2015, 2016), which will increase energy intake. Because energy and protein supply interact for milk protein synthesis (Oldham, 1984; Brun-Lafleur et al., 2010), increased milk protein yield in these studies may be a function of increased energy intake. In the current study, because no differences were observed for energy intake and utilization when supplementing RP His, the increase in milk protein yield with His may have not been large enough to affect energy utilization.

We hypothesized that increasing Lys and His supply would decrease $\mathrm{N}$ excretion, an effect supported by an increase in milk $\mathrm{N}$ secretion. However, the addition of neither RP Lys nor RP His affected $(P>0.16)$ fecal or urinary $\mathrm{N}$ excretion (Table 9). Although RP His increased milk protein production, RP His did not affect $(P>0.20)$ total milk $\mathrm{N}$ secretion. Variation for milk $\mathrm{N}$ secretion was about $16 \%$ greater (adjusted for units) 
Table 7. Oxygen consumption, carbon dioxide and methane production, respiratory quotient, and energy utilization of lactating Jersey cows fed a diet containing $5 \%$ hydrolyzed feather meal and supplemented with rumen-protected (RP) Lys and His

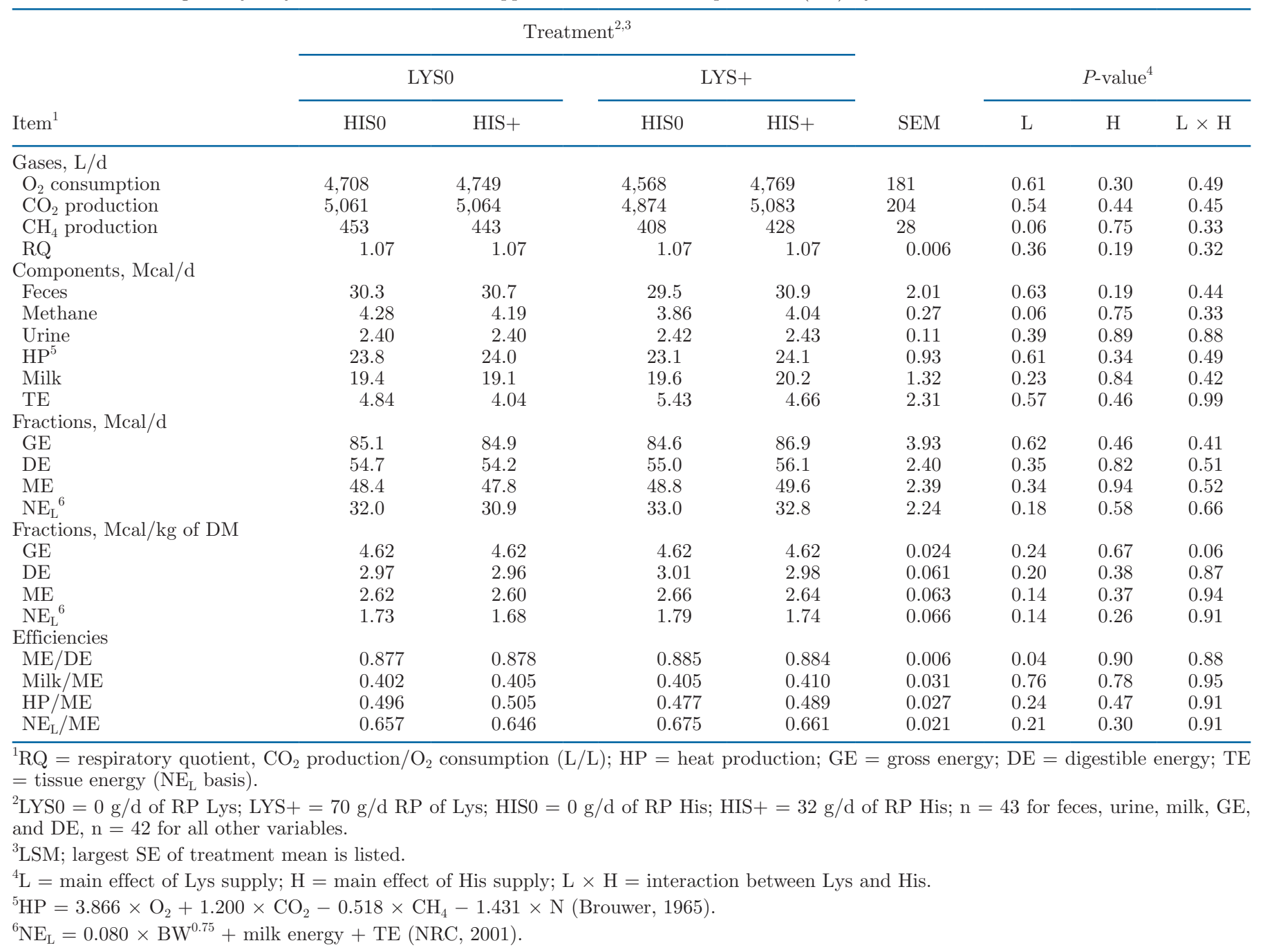

Table 8. Apparent total-tract digestibility of nutrients of lactating Jersey cows fed a diet containing $5 \%$ hydrolyzed feather meal and supplemented with rumen-protected (RP) Lys and His

\begin{tabular}{|c|c|c|c|c|c|c|c|c|}
\hline Item & \multicolumn{4}{|c|}{ Treatment $^{1,2}$} & SEM & \multicolumn{3}{|c|}{$P$-value ${ }^{3}$} \\
\hline DM & 65.7 & 65.2 & 66.6 & 66.1 & 1.20 & 0.07 & 0.36 & 0.99 \\
\hline $\mathrm{OM}$ & 67.1 & 66.7 & 68.0 & 67.5 & 1.22 & 0.09 & 0.38 & 0.93 \\
\hline NDF & 47.3 & 47.7 & 49.7 & 47.2 & 1.69 & 0.29 & 0.23 & 0.11 \\
\hline Starch & 95.6 & 94.5 & 95.9 & 95.7 & 0.66 & 0.06 & 0.09 & 0.25 \\
\hline Energy & 64.4 & 64.0 & 65.2 & 64.6 & 1.22 & 0.20 & 0.39 & 0.91 \\
\hline
\end{tabular}

${ }^{1} \mathrm{LYS} 0=0 \mathrm{~g} / \mathrm{d}$ of RP Lys; LYS $+=70 \mathrm{~g} / \mathrm{d}$ of RP Lys; HIS0 $=0 \mathrm{~g} / \mathrm{d}$ of RP His; HIS $+=32 \mathrm{~g} / \mathrm{d}$ of RP His; $\mathrm{n}=43$ for all variables.

${ }^{2} \mathrm{LSM}$; largest SE of treatment mean is listed.

${ }^{3} \mathrm{~L}=$ main effect of Lys supply; $\mathrm{H}=$ main effect of His supply; $\mathrm{L} \times \mathrm{H}=$ interaction between Lys and His.

${ }^{4} \mathrm{NDF}_{\mathrm{OM}}=\mathrm{NDF}$ corrected for ash. 
Table 9. Output of feces and urine and N utilization of lactating Jersey cows fed a diet containing $5 \%$ feather meal and supplemented with rumen-protected (RP) Lys and His

\begin{tabular}{|c|c|c|c|c|c|c|c|c|}
\hline Item & \multicolumn{4}{|c|}{ Treatment $^{1,2}$} & SEM & \multicolumn{3}{|c|}{$P$-value ${ }^{3}$} \\
\hline \multicolumn{9}{|c|}{ Output, $\mathrm{kg} / \mathrm{d}$ (as is) } \\
\hline Feces & 88.3 & 88.0 & 86.2 & 89.3 & 5.54 & 0.86 & 0.53 & 0.45 \\
\hline Urine & 23.1 & 23.3 & 23.5 & 23.2 & 1.37 & 0.83 & 0.92 & 0.77 \\
\hline \multicolumn{9}{|l|}{ Mass, g/d } \\
\hline Fecal N & 191 & 193 & 185 & 193 & 13 & 0.49 & 0.31 & 0.55 \\
\hline Urinary $\mathrm{N}$ & 162 & 165 & 161 & 168 & 7 & 0.83 & 0.16 & 0.62 \\
\hline Milk N & 136 & 138 & 136 & 142 & 9 & 0.46 & 0.20 & 0.52 \\
\hline Retained N & 17 & 14 & 26 & 23 & 9 & 0.08 & 0.56 & 0.91 \\
\hline \multicolumn{9}{|c|}{ As proportion of $\mathrm{N}$ intake, $\%$} \\
\hline Fecal N & 37.8 & 38.0 & 36.5 & 36.6 & 1.37 & 0.04 & 0.86 & 0.97 \\
\hline Urinary $\mathrm{N}$ & 31.9 & 32.5 & 31.7 & 32.0 & 1.02 & 0.58 & 0.49 & 0.84 \\
\hline
\end{tabular}

${ }^{1} \mathrm{LYS} 0=0 \mathrm{~g} / \mathrm{d}$ of RP Lys; LYS $+=70 \mathrm{~g} / \mathrm{d}$ of RP Lys; HIS0 $=0 \mathrm{~g} / \mathrm{d}$ of RP His; HIS $+=32 \mathrm{~g} / \mathrm{d}$ of RP His; $\mathrm{n}=43$ for all variables.

${ }^{2} \mathrm{LSM}$; largest SE of treatment mean is listed.

${ }^{3} \mathrm{~L}=$ main effect of Lys supply; $\mathrm{H}=$ main effect of His supply; $\mathrm{L} \times \mathrm{H}=$ interaction between Lys and His.

compared with milk protein yield. Therefore, although secretion of milk $\mathrm{N}$ was directionally increased by a similar quantity as $\mathrm{N}$ output from increased milk protein $(\sim 4 \mathrm{~g} / \mathrm{d})$, increased variation for milk $\mathrm{N}$ secretion may have limited our ability to observe differences in milk N secretion. Similar to our observations, N utilization was not affected when RP AA were supplemented compared with unsupplemented treatments (Lee et al., 2012, 2015). Supplementing RP Lys tended ( $P=$ $0.08)$ to increase retained $\mathrm{N}$ ( 25 vs. $16 \pm 9 \mathrm{~g} / \mathrm{d}$ ). With abomasal infusion of EAA to increase MP and improve AA profile, Nichols et al. (2019) observed an increase in $\mathrm{N}$ balance. Increased $\mathrm{N}$ balance with RP Lys suggests that increasing Lys supply improved AA profile and allowed for increased protein synthesis in non-mammary tissues. This response agrees with decreased protein mobilization suggested by decreased 3-methylhistidine with supplemental RP Lys.

\section{CONCLUSIONS}

Supplementing RP Lys increased plasma Lys only when RP His was not supplemented, whereas supplementing RP His increased plasma His. Supplementing RP His to a diet containing HFM increased milk and milk protein yield, whereas supplementing RP Lys did not affect milk production, nor did it affect milk components. Supplemental RP Lys or His did not affect utilization of energy, except for an unexpected decrease in methane with RP Lys. With increased Lys, $\mathrm{N}$ balance increased and plasma 3-methylhisitidine decreased, which suggests an increase in protein accretion and decrease in protein mobilization. A lack of production response to added Lys suggest that the EAA may not have been limiting for milk protein synthesis, or the increase in Lys supply may not have been large enough to increase milk protein. Increased milk yield and milk protein yield suggest that His may be a potentially limiting AA in diets containing hydrolyzed feather meal fed to lactating dairy cows.

\section{ACKNOWLEDGMENTS}

The authors thank the University of Nebraska Dairy Metabolism (Lincoln, NE) staff and students for care of the experimental animals and assistance with collections, the Poultry Protein and Fat Council (Tucker, GA) for financial support, and Balchem Corp. (New Hampton, NY) for supplying the RP His. The authors state no conflicts of interest.

\section{REFERENCES}

Akamatsu, H., Y. Saitoh, M. Serizawa, K. Miyake, Y. Ohba, and K. Nakashima. 2007. Changes of serum 3-methylhistidine concentration and energy-associated metabolites in dairy cows with ketosis. J. Vet. Med. Sci. 69:1091-1093. https://doi.org/10.1292/jvms.69 1091.

AOAC International. 2000. Official Methods of Analysis, Vol. 1 and 2 17th ed. AOAC International, Gaithersburg, MD.

Appuhamy, J. A., J. R. Knapp, O. Becvar, J. Escobar, and M. D. Hanigan. 2011. Effects of jugular-infused lysine, methionine, and branched-chain amino acids on milk protein synthesis in high-producing dairy cows. J. Dairy Sci. 94:1952-1960. https://doi.org/10 .3168/jds.2010-3442.

Appuhamy, J. A., J. France, and E. Kebreab. 2016. Models for predicting enteric methane emissions from dairy cows in North Amer- 
ica, Europe, and Australia and New Zealand. Glob. Chang. Biol. 22:3039-3056. https://doi.org/10.1111/gcb.13339.

Arriola Apelo, S. A., A. Bell, K. Estes, J. Ropelewski, M. de Veth, and M. Hanigan. 2014. Effects of reduced dietary protein and supplemental rumen-protected essential amino acids on the nitrogen efficiency of dairy cows. J. Dairy Sci. 97:5688-5699. https://doi.org/ 10.3168/jds.2013-7833.

Brouwer, E. 1965. Report of sub-committee on constants and factors. Pages 441-443 in Proc. 3rd Symposium of Energy Metabolism. Academic Press, London, UK.

Brun-Lafleur, L., L. Delaby, F. Husson, and P. Faverdin. 2010. Predicting energy $\times$ protein interaction on milk yield and milk composition in dairy cows. J. Dairy Sci. 93:4128-4143. https://doi .org/10.3168/jds.2009-2669 https://doi.org/doi.org/10.3168/jds $.2009-2669$.

Buse, K. K., D. L. Morris, and P. J. Kononoff. 2019. Ruminal degradation and intestinal digestibility of hydrolyzed feather meal with and without blood. J. Dairy Sci. 102(Suppl. 2):M14 (Abstr.).

Deyl, Z., J. Hyanek, and M. Horakova. 1986. Profiling of amino acids in body fluids and tissues by means of liquid chromatography. J. Chromatogr. 379:177-250. https://doi.org/10.1016/S0378 $-4347(00) 80685-4$.

DuBois, M., K. A. Gilles, J. K. Hamilton, P. Rebers, and F. Smith. 1956. Colorimetric method for determination of sugars and related substances. Anal. Chem. 28:350-356. https://doi.org/10.1021/ ac60111a017.

Fekkes, D. 1996. State-of-the-art of high-performance liquid chromatographic analysis of amino acids in physiological samples. J. Chromatogr. B Biomed. Appl. 682:3-22. https://doi.org/10.1016/0378 $-4347(96) 00057-6$.

Fleming, A. J., K. A. Estes, H. Choi, B. A. Barton, C. A. Zimmerman, and M. D. Hanigan. 2019a. Assessing bioavailability of ruminally protected methionine and lysine prototypes. J. Dairy Sci. 102:4014-4024. https://doi.org/10.3168/jds.2018-14667.

Fleming, A. J., H. Lapierre, R. R. White, H. Tran, P. J. Kononoff, R. Martineau, W. P. Weiss, and M. D. Hanigan. 2019b. Predictions of ruminal outflow of essential amino acids in dairy cattle. J. Dairy Sci. 102:10947-10963. https://doi.org/10.3168/jds.2019-16301.

Foth, A. J., T. Brown-Brandl, K. J. Hanford, P. S. Miller, G. Garcia Gomez, and P. J. Kononoff. 2015. Energy content of reduced-fat dried distillers grains with solubles for lactating dairy cows. J. Dairy Sci. 98:7142-7152. https://doi.org/10.3168/jds.2014-9226.

Freetly, H. C., J. A. Nienaber, and T. Brown-Brandl. 2006. Partitioning of energy during lactation of primiparous beef cows. J. Anim. Sci. 84:2157-2162. https://doi.org/10.2527/jas.2005-534.

Giallongo, F., M. T. Harper, J. Oh, J. C. Lopes, H. Lapierre, R. A. Patton, C. Parys, I. Shinzato, and A. N. Hristov. 2016. Effects of rumen-protected methionine, lysine, and histidine on lactation performance of dairy cows. J. Dairy Sci. 99:4437-4452. https://doi .org/10.3168/jds.2015-10822.

Giallongo, F., M. T. Harper, J. Oh, C. Parys, I. Shinzato, and A. N. Hristov. 2017. Histidine deficiency has a negative effect on lactational performance of dairy cows. J. Dairy Sci. 100:2784-2800. https://doi.org/10.3168/jds.2016-11992.

Giallongo, F., A. Hristov, J. Oh, T. Frederick, H. Weeks, J. Werner, H. Lapierre, R. Patton, A. Gehman, and C. Parys. 2015. Effects of slow-release urea and rumen-protected methionine and histidine on performance of dairy cows. J. Dairy Sci. 98:3292-3308. https:/ /doi.org/10.3168/jds.2014-8791.

Goering, H. K., and P. J. Van Soest. 1970. Forage fiber analyses. USDA Agricultural Research Service Handbook No. 379. US Government Printing Office, Washington, DC.

Hall, M. B. 2009. Determination of starch, including maltooligosaccharides, in animal feeds: Comparison of methods and a method recommended for AOAC collaborative study. J. AOAC Int. 92:42-49. https://doi.org/10.1093/jaoac/92.1.42.

Harris, C. I. 1981. Reappraisal of the quantitative importance of nonskeletal-muscle source of $\mathrm{N} \tau$-methylhistidine in urine. Biochem. J. 194:1011-1014. https://doi.org/10.1042/bj1941011.

Heinrichs, A. J., and P. J. Kononoff. 2002. Evaluating particle size of forages and TMRs using the new Penn State Forage Particle Sepa- rator. Technical Bulletin DAS 02-42. College Agric. Sci., Cooperative Ext., Pennsylvania State University, University Park, PA.

Huhtanen, P., A. Vanhatalo, and T. Varvikko. 2002. Effects of abomasal infusions of histidine, glucose, and leucine on milk production and plasma metabolites of dairy cows fed grass silage diets. J. Dairy Sci. 85:204-216. https://doi.org/10.3168/jds.S0022 -0302(02)74069-1.

Kononoff, P. J., and K. J. Hanford. 2006. Technical note: Estimating statistical power of mixed models used in dairy nutrition experiments. J. Dairy Sci. 89:3968-3971. https://doi.org/10.3168/jds S0022-0302(06)72439-0.

Kuznetsova, A., P. B. Brockhoff, and R. H. B. Christensen. 2017. lmerTest package: Tests in linear mixed effects models: Version 3.0-1. Accessed November 28, 2019. https://cran.r-project.org/ web/packages/lmerTest/index.html.

Lapierre, H., L. Doepel, E. Milne, and G. Lobley. 2009. Responses in mammary and splanchnic metabolism to altered lysine supply in dairy cows. Animal 3:360-371. https://doi.org/10.1017/ S1751731108003571.

Lapierre, H., G. Lobley, L. Doepel, G. Raggio, H. Rulquin, and S. Lemosquet. 2012. Triennial Lactation Symposium: Mammary metabolism of amino acids in dairy cows. J. Anim. Sci. 90:1708-1721. https://doi.org/10.2527/jas.2011-4645.

Lapierre, H., D. Ouellet, L. Doepel, G. Holtrop, and G. Lobley. 2008 Histidine, lysine and methionine: From metabolism to balanced dairy rations. Pages 19-36 in Proc. 44th Eastern Nutrition Conference of the Animal Nutrition Association of Canada (ANAC), University of Guelph, Guelph, ON, Canada.

Lee, C., F. Giallongo, A. N. Hristov, H. Lapierre, T. W. Cassidy, K. S. Heyler, G. A. Varga, and C. Parys. 2015. Effect of dietary protein level and rumen-protected amino acid supplementation on amino acid utilization for milk protein in lactating dairy cows. J. Dairy Sci. 98:1885-1902. https://doi.org/10.3168/jds.2014-8496.

Lee, C., A. N. Hristov, K. S. Heyler, T. W. Cassidy, H. Lapierre, G. A. Varga, and C. Parys. 2012. Effects of metabolizable protein supply and amino acid supplementation on nitrogen utilization, milk production, and ammonia emissions from manure in dairy cows. J. Dairy Sci. 95:5253-5268. https://doi.org/10.3168/jds.2012-5366.

Manjarin, R., B. J. Bequette, G. Wu, and N. L. Trottier. 2014. Linking our understanding of mammary gland metabolism to amino acid nutrition. Amino Acids 46:2447-2462. https://doi.org/10.1007/ s00726-014-1818-8.

Martineau, R., D. Ouellet, E. Kebreab, R. White, and H. Lapierre. 2017. Relationships between postruminal casein infusion and milk production, and concentrations of plasma amino acids and blood urea in dairy cows: A multilevel mixed-effects meta-analysis. J. Dairy Sci. 100:8053-8071. https://doi.org/10.3168/jds.2016-11813.

Martineau, R., D. R. Ouellet, R. A. Patton, R. R. White, and H. Lapierre. 2019. Plasma essential amino acid concentrations in response to casein infusion or ration change in dairy cows: A multilevel, mixed-effects meta-analysis. J. Dairy Sci. 102:1312-1329. https:// doi.org/10.3168/jds.2018-15218.

Moraes, L. E., E. Kebreab, A. B. Strathe, J. Dijkstra, J. France, D. P. Casper, and J. G. Fadel. 2015. Multivariate and univariate analysis of energy balance data from lactating dairy cows. J. Dairy Sci. 98:4012-4029. https://doi.org/10.3168/jds.2014-8995.

Morris, D. L., J. V. Judy, and P. J. Kononoff. 2020. Use of indirect calorimetry to evaluate utilization of energy in lactating Jersey dairy cattle consuming diets with increasing inclusion of hydrolyzed feather meal. J. Dairy Sci. https://doi.org/10.3168/jds.2019 -17762 .

Nichols, K., A. Bannink, and J. Dijkstra. 2019. Energy and nitrogen balance of dairy cattle as affected by provision of different essential amino acid profiles at the same metabolizable protein supply. J. Dairy Sci. 102:8963-8976. https://doi.org/10.3168/jds.2019-16400.

Nienaber, J., and A. Maddy. 1985. Temperature controlled multiple chamber indirect calorimeter-Design and operation. Trans. ASAE 28:555-0560. https://doi.org/10.13031/2013.32297.

NRC. 2001. Nutrient Requirements of Dairy Cattle. 7th rev. ed. National Academies Press, Washington, DC 
Oldham, J. D. 1984. Protein-energy interrelationships in dairy cows. J. Dairy Sci. 67:1090-1114. https://doi.org/10.3168/jds.S0022 $-0302(84) 81410-1$.

Patton, R. A., A. N. Hristov, C. Parys, and H. Lapierre. 2015. Relationships between circulating plasma concentrations and duodenal flows of essential amino acids in lactating dairy cows. J. Dairy Sci. 98:4707-4734. https://doi.org/10.3168/jds.2014-9000.

Paz, H. A., M. J. de Veth, R. S. Ordway, and P. J. Kononoff. 2013. Evaluation of rumen-protected lysine supplementation to lactating dairy cows consuming increasing amounts of distillers dried grains with solubles. J. Dairy Sci. 96:7210-7222. https://doi.org/ 10.3168/jds.2013-6906.

Paz, H. A., T. J. Klopfenstein, D. Hostetler, S. C. Fernando, E. Castillo-Lopez, and P. J. Kononoff. 2014. Ruminal degradation and intestinal digestibility of protein and amino acids in high-protein feedstuffs commonly used in dairy diets. J. Dairy Sci. 97:64856498. https://doi.org/10.3168/jds.2014-8108.

Paz, H. A., and P. J. Kononoff. 2014. Lactation responses and amino acid utilization of dairy cows fed low-fat distillers dried grains with solubles with or without rumen-protected lysine supplementation. J. Dairy Sci. 97:6519-6530. https://doi.org/10.3168/jds.2014-8315.

Reynolds, M. A., T. M. Brown-Brandl, J. V. Judy, K. J. Herrick, K. E. Hales, A. K. Watson, and P. J. Kononoff. 2019. Use of indirect calorimetry to evaluate utilization of energy in lactating Jersey dairy cattle consuming common coproducts. J. Dairy Sci. 102:320-333. https://doi.org/10.3168/jds.2018-15471.

Robinson, P. H. 2010. Impacts of manipulating ration metabolizable lysine and methionine levels on the performance of lactating dairy cows: A systematic review of the literature. Livest. Sci. 127:115126. https://doi.org/10.1016/j.livsci.2009.10.003.

Schwab, C., P. Huhtanen, C. Hunt, and T. Hvelplund. 2005. Nitrogen requirements of cattle. Pages 13-70 in Nitrogen and Phosphorus Nutrition of Cattle and Environment. E. Pfeffer and A. N. Hristov, ed. CAB International, Wallingford, UK.

Sok, M., D. R. Ouellet, J. L. Firkins, D. Pellerin, and H. Lapierre. 2017. Amino acid composition of rumen bacteria and protozoa in cattle. J. Dairy Sci. 100:5241-5249. https://doi.org/10.3168/ jds.2016-12447.
Stahel, P., N. Purdie, and J. Cant. 2014. Use of dietary feather meal to induce histidine deficiency or imbalance in dairy cows and effects on milk composition. J. Dairy Sci. 97:439-445. https://doi.org/10 .3168/jds.2013-7269.

Tyrrell, H. F., and J. T. Reid. 1965. Prediction of the energy value of cow's milk. J. Dairy Sci. 48:1215-1223. https://doi.org/10.3168/ jds.S0022-0302(65)88430-2.

Van Soest, P. J., J. B. Robertson, and B. A. Lewis. 1991. Methods for dietary fiber, neutral detergent fiber, and nonstarch polysaccharides in relation to animal nutrition. J. Dairy Sci. 74:3583-3597. https://doi.org/10.3168/jds.S0022-0302(91)78551-2.

Vanhatalo, A., P. Huhtanen, V. Toivonen, and T. Varvikko. 1999. Response of dairy cows fed grass silage diets to abomasal infusions of histidine alone or in combinations with methionine and lysine. J. Dairy Sci. 82:2674-2685. https://doi.org/10.3168/jds.S0022 -0302(99)75524-4.

Vyas, D., and R. A. Erdman. 2009. Meta-analysis of milk protein yield responses to lysine and methionine supplementation. J. Dairy Sci. 92:5011-5018. https://doi.org/10.3168/jds.2008-1769.

Yoder, P. S., X. Huang, I. A. Teixeira, J. P. Cant, and M. D. Hanigan. 2020. Effects of jugular infused methionine, lysine, and histidine as a group or leucine and isoleucine as a group on production and metabolism in lactating dairy cows. J. Dairy Sci. 103:2387-2404. https://doi.org/10.3168/jds.2019-17082.

Zang, Y., L. H. P. Silva, M. Ghelichkhan, M. Miura, N. L. Whitehouse, M. L. Chizzotti, and A. F. Brito. 2019. Incremental amounts of rumen-protected histidine increase plasma and muscle histidine concentrations and milk protein yield in dairy cows fed a metabolizable protein-deficient diet. J. Dairy Sci. 102:4138-4154. https:// doi.org/10.3168/jds.2018-15780.

\section{ORCIDS}

D. L. Morris (® https://orcid.org/0000-0001-6347-2804

P. J. Kononoff $\odot$ https://orcid.org/0000-0001-6069-2174 